\title{
DIFFERENT MODELS FOR ESTIMATING GENETIC PARAMETERS FOR GROWTH TRAITS OF HOLSTEIN- FRIESIAN UNDER SEMITROPICAL CONDITIONS
}

\author{
M. H. Sadek ${ }^{1}$, A. R. Shemeis ${ }^{1}$ and N. A. Shalaby ${ }^{2}$ \\ 1- Department of Animal Production, Faculty of Agriculture, Ain Shams \\ University, P. O. Box 68 Hadayek Shoubra, 11241, Cairo, Egypt, 2- Department of \\ Animal Production, Faculty of Agriculture, Mansoura University, Mansoura, \\ Egypt
}

\section{SUMMARY}

Estimates of genetic parameters resulting from three different models for birth weight, weaning weight, yearling weight and total gain were compared.

Data consisted of 823 Holstein-Friesian animals progenies of 25 sires and 459 dams in a single herd. The MTDFREML programs were used to estimate heritabilities, predicted transmitting abilities (PTA) and genetic correlations. The three models compared were: Model I, a sire model, included year-season of birth and sex of calf as fixed effects and sire as random effect. Model II, a sire-dam model, included, in addition to the effects in model I, dam as a second random effect. Model III, a full animal model, included, in addition to the fixed effects of model I, animal additive direct genetic effect, maternal genetic effect and permanent environmental effect, as three random effects.

The likelihood function showed that the full animal model best fit the data. Heritability estimates and genetic correlations obtained from model III were higher than those obtained from models I and II for all traits. Models I and II resulted in changes in ranking for PTA in contrast with model III.

In conclusion, full animal model could be most appropriate for estimating genetic parameters for growth traits than the sire or the sire-dam models.

Keywords: Growth, animal model, heritability, genetic correlation, predicted transmitting ability

\section{INTRODUCTION}

Although Holstein-Friesian is considered as dairy animals, the growth of these animals is of great importance. Extra male calves are grown as meat animals and female calves are grown as replacement heifers. Studies have indicated that when prepubertal growth rates of heifers increase, time to conception, age at first calving, and milk yield during first lactation decrease (Swanson,1960, Grander et al., 1977, and Little and Kay, 1979). During the prepubertal period of heifer growth, the mammary gland is sensitive to body weight gain (Sejrsen et al., 1982, Sejrsen et al., 1983, Peticlerc et al., 1984). Koenen and Groen (1996) reported that the expected increase in profitability was 2 to $4 \%$ when body weight was included in the breeding

Issued by The Egyptian Society of Animal Production 
goal and in the selection index due to the relationship between body weight and production traits. Van Amburgh et al. (1998) indicated that milk yield was significantly reduced for heifers grown at $0.94 \mathrm{~kg} / \mathrm{d}$ compared with that of heifers grown at $0.68 \mathrm{~kg} / \mathrm{d}$. However, Mercadante et al. (2003) concluded that selection for body weight promoted high and consistent weight response for both yearling and later ages, without compromising the reproductive performance of the cows with respect to days to calving and calving success. There is evidence that changes in performance of animals with age are influenced by genetic factors (Atchley et al., 1997 and Atchley, 1998). Growth traits in cattle are important in selection program. Therefore, estimating the genetic parameters for some growth traits and implement them in a selection program would be of great importance.

The estimation of variance and covariance components, hence estimating genetic parameters, evolved from Henderson's Methods I and III (Henderson, 1953), through the mixed models methodology (Henderson, 1988). The Restricted Maximum Likelihood, REML, (co)variance component estimation is the most commonly used algorithm in such estimation utilizing different mixed models.

The objectives of the present work were to compare estimates of genetic parameters for birth weight (BWT), weaning weight (WWT), yearling weight (YWT) and total gain (TG) from Holstein-Friesian cattle using different statistical models to determine whether simpler models produce estimates similar to those produced by more complex alternatives.

\section{MATERIAL AND METHODS}

Data were 823 records for Holstein-Friesian cattle from one herd owned by the Egyptian Company for Meat and Milk Production, Faraskour, Damietta collected from 1988 to 1994. Animals were housed in semi-roofed yards. Animals were feed after weaning on concentrate mixture and roughage such as rice straw and green Egyptian clover (Trifolium alexandrinum) or its hay $\}$. Feeding allowances were calculated according to NRC (1981). Fresh and clean water was available all times.

Data included 271 male calves and 552 female calves. These calves were progenies of 25 sires and 459 dams. Two seasons were defined, from April to September and from October to March. Hence, 14 year-seasons were identified. Four traits were selected for analyses: birth weight (BWT), weaning weight (WWT) at 100 days of age, yearling weight (YWT) and total gain (TG) from birth to 12 months of age. Table 1 lists descriptive statistics of the records for the four traits evaluated for whole data and for both sexes.

\section{MODELS:}

Three models were used to estimate genetic and phenotypic parameters for the four traits. They included heritability for each trait and genetic and phenotypic correlations between different traits. The first model (Model I) was the sire model. The second (Model II) was the sire-dam model. The third (Model III) was the animal model that included the animal direct genetic effect, the maternal genetic effect, and the permanent environmental effect.

The equation for model III for multiple traits was as follows:

$$
\mathrm{y}=\mathrm{Xb}+\mathrm{Za}+\mathrm{Mm}+\mathrm{Wp}+\mathrm{e}
$$


where:

$y$ is a vector of observations of the four traits:

$b$ is a vector of fixed effects (year-season of birth and sex of calf);

$\mathrm{a}$ is a vector of random additive direct genetic effects;

$\mathrm{m}$ and $\mathrm{p}$ are vectors of random maternal genetic and permanent environmental effects;

$\mathrm{e}$ is a vector of random residual effect; and

$\mathrm{X}, \mathrm{Z}, \mathrm{M}$ and $\mathrm{W}$ are known incidence matrices relating observations to the respective fixed and random effects with $\mathrm{Z}$ and $\mathrm{M}$ augmented with columns of zeros for animals without records.

The first and the second moments of the model were assumed to be:

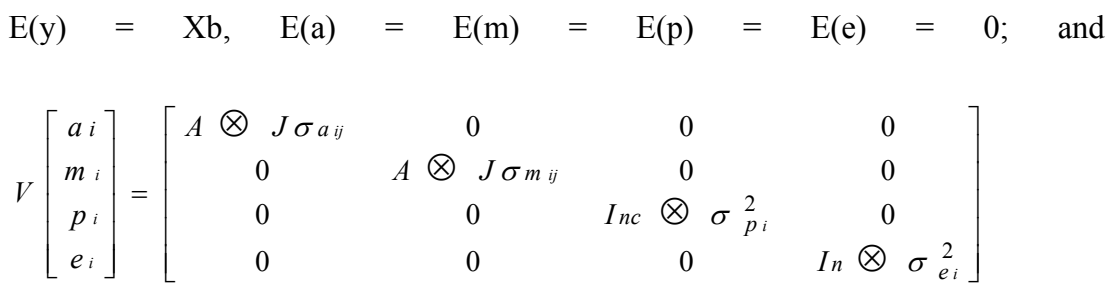

$\mathrm{A}$ is the additive numerator relationship matrix for animals. $\mathrm{J}$ is a matrix of 1 's of order $4 \times 4 . I_{n c}$ and $I_{n}$ are identity matrices of order equal to the number of dams (nc) and to the total number of animals $(n)$, respectively. $\otimes$ means the direct product of two matrices. Subscripts $i$ and $j$ refer to the four traits $(i=j=1$ to 4$)$. When $i=j$, it means the diagonal which is the variance. When $i \neq j$, it means the off diagonal, which is the covariance. All random effects were considered uncorrelated.

Model I (sire model) and model II (sire-dam model) included the same fixed effects as model III. Model I included the sire only as random effect. Model II included the sire and the dam as two random effects. Therefore, the differences among the models refer to the number of random effects considered.

Genetic parameters were estimated for the three models with derivative-free REML (Meyer, 1989) using multiple-trait derivative free restricted maximum likelihood (MTDFREML) programs (Boldman et al, 1995). The method involves maximizing the likelihood function $(\Lambda)$ given the data and is the same as maximizing $\log \Lambda$ or minimizing $-2 \log \Lambda$. Heritability estimates obtained from model II were calculated based on sire and dam variance components as $2\left(\sigma_{s}^{2}+\sigma_{d}^{2}\right) / \sigma_{p}^{2}$, where $\sigma_{s}^{2}$, $\sigma_{d}^{2}$, and $\sigma_{p}^{2}$ were sire, dam and total variance components, respectively.

To compare models each trait was reanalyzed as a single trait with the three different models to obtain the log likelihood value. It was assumed that the higher the likelihood function the more the model explained the data. Likelihood function is higher when new parameters are added to the model. Comparisons of the different models were made with likelihood-ratio test. The differences between the function values for pairs of models can be tested against the chi-square distribution with degrees of freedom being the difference in number of variance or covariance components in the models (Dobson, 1990). This method is based on the property that the difference $-2\left[\log \Lambda_{\mathrm{i}}-\log \Lambda_{\mathrm{i}}\right]$ has chi-squared distribution, where $\Lambda_{\mathrm{i}}$ and $\Lambda_{\mathrm{i}}$, are the values of likelihood function. 
Table 1. Descriptive statistics for records for birth weight (BWT), weaning weight (WWT), yearling weight (YWT) and total gain (TG), kg

\begin{tabular}{lrrrr}
\hline Item & BWT & WWT & YWT & \multicolumn{1}{c}{ TG } \\
\hline Whole data ( 823 records): & & & & \\
Mean & 30.3 & 74.4 & 219.4 & 189.1 \\
Standard deviation & 4.9 & 13.5 & 32.8 & 31.5 \\
Coefficient of variation \% & 16.1 & 18.1 & 14.9 & 16.7 \\
Male calves ( 271 records): & & & & \\
Mean & 32 & 76.3 & 223.5 & 191.5 \\
Standard deviation & 4.8 & 14 & 34 & 33 \\
Coefficient of variation \% & 15 & 18.3 & 15.2 & 17.2 \\
Female calves ( 552 records): & & & & \\
Mean & 29.4 & 73.4 & 217.3 & 187.9 \\
Standard deviation & 4.7 & 13.1 & 32 & 30.7 \\
Coefficient of variation \% & 15.8 & 17.9 & 14.7 & 16.3 \\
\hline
\end{tabular}

\section{RESULTS AND DISCUSSION}

The definition of the correct model that better fits the data is very important. Table 2 shows the calculated chi-square values for the difference between different models in the log likelihood functions. This test showed a significant difference between the animal model and both the sire and sire-dam models for all traits except birth weight and weaning weight where there was no significance difference between the animal model and the sire-dam model for both traits. The log likelihood showed a better fit with the animal model than with sire or sire-dam models. These results agree with Ferreira et al. (1999).

Table 3 shows estimates of heritability and genetic correlation from different models. In general, there was an increase in the estimate of heritability for all traits by adding more random effects to the model with different magnitude. They ranged from 0.27 and 0.49 for birth weight, 0.17 and 0.28 for weaning weight, 0.14 and 0.32 for yearling weight and 0.11 and 0.21 for total gain, using the sire model and the animal model, respectively. Sire-dam model heritability estimates were within these ranges for all traits. Estimates of heritability from the animal model were comparable to that reported by Meyer (1993) and Koots et al. (1994). 
Table 2. Calculated chi-square values for likelihood test used to compare different models (sire model, Model I, sire-dam mode, Model II and animal model, Model III) for birth weight (BWT), weaning weight (WWT), yearling weight (YWT), and total gain (TG)

\begin{tabular}{lccc}
\hline & \multicolumn{3}{c}{ Comparison between models } \\
\cline { 2 - 4 } Trait & Model II - Model I & Model III - Model I & Model III - Model II \\
\hline BWT & $75^{* *}$ & $76.76^{* *}$ & $1.76^{\mathrm{NS}}$ \\
WWT & $115^{* *}$ & $118.25^{* *}$ & $3.25^{\mathrm{NS}}$ \\
YWT & $210^{* *}$ & $404^{* *}$ & $194^{* *}$ \\
TG & $195^{* *}$ & $346^{* *}$ & $151^{* *}$ \\
\hline${ }^{* *}$ Significant differen
\end{tabular}

Significant difference at $\mathrm{p}<0.01$

NS Not significant at $\mathrm{p}>0.05$

Table 3. Heritability (diagonal) estimates and genetic correlations (below diagonal) among birth weight (BWT), weaning weight (WWT), yearling weight (YWT), and total gain (TG) using different models

\begin{tabular}{|c|c|c|c|c|}
\hline Trait & BWT & WWT & YWT & TG \\
\hline & \multicolumn{4}{|c|}{ Model I (Sire model) } \\
\hline BWT & 0.27 & & & \\
\hline WWT & 0.46 & 0.17 & & \\
\hline YWT & 0.22 & 0.39 & 0.14 & \\
\hline \multirow[t]{2}{*}{ TG } & 0.39 & 0.31 & 0.79 & 0.11 \\
\hline & \multicolumn{4}{|c|}{ Model II (Sire-Dam model) } \\
\hline BWT & 0.29 & & & \\
\hline WWT & 0.51 & 0.18 & & \\
\hline YWT & 0.24 & 0.41 & 0.21 & \\
\hline \multirow[t]{2}{*}{ TG } & 0.41 & 0.38 & 0.88 & 0.14 \\
\hline & \multicolumn{4}{|c|}{ Model III (Animal model) } \\
\hline BWT & 0.49 & & & \\
\hline WWT & 0.65 & 0.28 & & \\
\hline YWT & 0.31 & 0.43 & 0.32 & \\
\hline TG & 0.45 & 0.48 & 0.95 & 0.21 \\
\hline
\end{tabular}

Genetic correlation showed same trend as the heritability estimates. Genetic correlation estimates obtained from the animal model were in general higher than that obtained from the sire or the sire-dam model. It ranged from 0.22 between birth weight and yearling weigh using the sire model to 0.95 between yearling weight and total gain using the animal model.

Table 4 shows the product moment and rank correlations between PTA values using the animal model and with the sire and the sire-dam models. Correlation between PTA values and ranks using the animal model with those using the sire-dam model were higher than the correlations with the sire model for all traits. These results were similar to that obtained by Ferreira et al. (1999). They suggest that the sire and/or the sire-dam models may not be adequate for estimating genetic parameters for growth traits if the full animal model can be assumed to be most appropriate. 
Table 4. Product moment and rank correlations between PTA values using the animal model (Model III) and using the sire-model (Model I) and the sire-dammodel (Model II) for birth weight, weaning weight, yearling weight and total gain

\begin{tabular}{lcc} 
Trait & Model III and Model I & Model III and Model II \\
\hline Birth weight: & & \\
$\quad$ Product moment correlation & 0.76 & 0.82 \\
$\quad$ Rank correlation & 0.74 & 0.81 \\
Weaning weight: & 0.67 & 0.73 \\
$\quad$ Product moment correlation & 0.62 & 0.69 \\
$\quad$ Rank correlation & 0.58 & 0.63 \\
Yearling weight: & 0.55 & 0.61 \\
$\quad$ Product moment correlation & & \\
$\quad$ Rank correlation & 0.64 & 0.68 \\
Total gain: & 0.61 & 0.63 \\
$\quad$ Product moment correlation & & \\
$\quad$ Rank correlation & &
\end{tabular}

\section{CONCLUSIONS}

Selection of the correct model is very important, because the more complex the model, the larger the time needed for solution. However, increasing the accuracy of estimation by adding more effects to the model that better explain the data would be more important than saving the time needed for solution. Full animal model generally had higher estimates of heritability and genetic correlation for birth weight, weaning weight, yearling weight and total gain than sire or sire-dam models. In addition, the likelihood function test showed a better fit with the full animal model than the sire or the sire-dam models. However, there was no significance difference in the likelihood function between the animal model and the sire-dam model for birth weight and weaning weight. Correlations and ranks between estimated TA values from the animal model and the sire and the sire-dam models suggest that that the animal model could be more appropriate for estimating genetic parameters for growth traits.

\section{REFERENCES}

Atchley, W. R., 1998. Development quantitative genetics: Age-specific response to selection. $6^{\text {th }}$ WCGALP. 26:505-512.

Atchley, W. R., S. Xu and D. E. Cowley, 1997. Altering developmental trajectories in mice by restricted index selection. Genetics. 146:629-640.

Boldman, K. G., L. A. Kriese, L. D. Van Vleck, C. P. Van Tassell and S. D. Kachman, 1995. A manual for use of MTDFREML. A set of programs to obtain estimates of variances and covariance [DRAFT]. p 114. USDA, ARS, Washington, DC, USA.

Dobson, A. J., 1990. An Introduction to Generalized Linear Models. p. 57. Chapman and Hall, New York. 
Ferreira, G. B., M. D. MacNeil, and L. D. Van Vleck, 1999. Variance components and breeding values for growth traits from different statistical models. J. Anim. Sci. 77:2641-2650.

Grander, R. W., J. D. Schum and L. G. Vargus, 1977. Accelerated growth and early breeding of Holstein heifers. J. Dairy Sci. 60:1941-1948.

Henderson, C. R., 1953. Estimation of variance and covariance components. Biometrics 9:226-256.

Henderson, C. R., 1988. Theoretical basis and computational method for a number of different animal models. J. Dairy Sci. 71:1-16/supplement 2.

Koenen, E. P. C. and A. F. Groen, 1996. Genetic analysis of growth patterns of black and white dairy heifers. J. Dairy Sci. 79:495-501.

Koots, K. R., J. P. Gibson, C. Smith and W. Wilton, 1994. Analyses of published parameter estimates for beef production traits. 1. Heritability. Anim. Breeding Abst. 62:309-338.

Little, W. and R. M. Kay, 1979. The effect of rapid rearing and early calving on subsequent performance of dairy heifers. Anim. Prod. 29:131-142.

Mercadante, M. E. Z., I. U. Packer, A.G. Razook, J. N. S. G. Cyrillo and L. A. Figueiredo, 2003. Direct and correlated responses to selection for yearling weight on reproductive performance of Nelore cows. J. Anim. Sci. 81:376-384.

Meyer, K., 1989. Restricted Maximum Likelihood to estimate variance components for animal models with several random effects, using a derivative-free algorithm. Genet. Sel. Evol. 21:317-340.

Meyer, K., 1993. Estimates of direct and maternal correlations among growth traits in Australian beef cattle. Livest. Prod. Sci. 8:121-13.

NRC., 1981. Nutrient requirements of domestic animals. National Research Council, Washington D. C.

Peticlerc, D., L. T. Chapin and H. A. Tucker, 1984. Carcass composition and mammary development response to photoperiod and plan of nutrition in Holstein heifers. J. Anim. Sci. 58:913-919.

Sejrsen, K., J. T. Huber and H. A. Tucker, 1983. Influence of amount fed on hormone concentrations and their relationship to mammary growth in heifers. J. Dairy Sci. 66:845-855.

Sejrsen, K., J. T. Huber, H. A. Tucker and R. A. Akers, 1982. Influence of nutrition on mammary development in pre- and postpubertal heifers. J. Dairy Sci. 65:793800 .

Swanson, E. W., 1960. Effect of raid growth with fattening of dairy heifers on their lactational ability. J. Dairy Sci. 43:377-387.

Van Amburgh, M. E., D. M. Galton, D. E. Bauman, R. W. Everett, D. G. Fox, L. E. Chase and H. N. Erb, 1998. Effects of three prepubertal body growth rates on performance of Holstein heifers during first lactation. J. Dairy Sci. 81:527-538. 
نماذج مختلفة لتقدير المعالم الوراثية لصفات النمو للهولستين- فرزيان تحت الظروف شبه الحارة

محمد حسين صادق 1، احمد راغب شميس و ناظم عبد الرحمن شلبى2 2

1 - قسم الإنتاج الحيوانى- كلية الزراعة - جامعة عين شهس- مصر ، 2 ـ قسم الإنتاج الحيوانى - كلية الززراعة - جامعة المنصورة - المنصورة - مصر - المصن

تمت مقارنة المعالم الوراثية المقدرة الناتجة من ثلاثة نماذج مختلفة لكل من وزن الميلاد، وزن الفطام،

الوزن عند عمر سنة، وإجمالى الزيادة الوزنية.

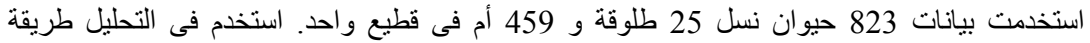
لحساب المكافئات الور اثية و القيم المنوقعة للققرة المرورية لكل صفة وكذلك الارتباط الور اثىى

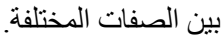

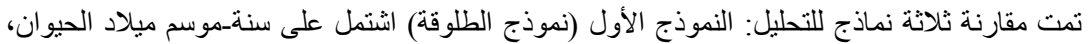

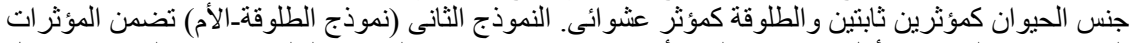

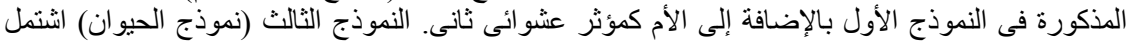

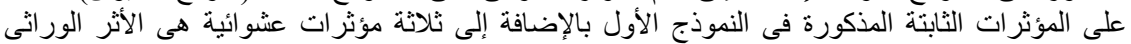
التجمعى للحيوان ، الأثر الور اثى الأمى ، الأثر البيئ الدائم.

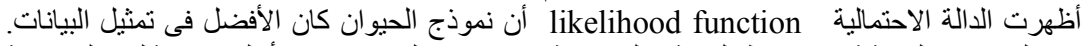

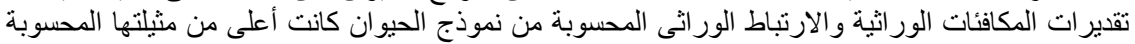

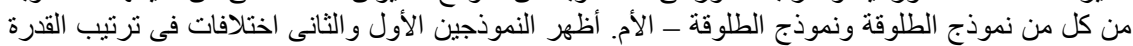

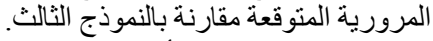
خلصت الدراسة إلى أن نموذج الحيوان هو الأفضل لتقييم الطلائق لصفات النمو مقارنة بنموذج الطلوقة أو 